\title{
In Memoriam: Janez Stanonik (1922-2014)
}

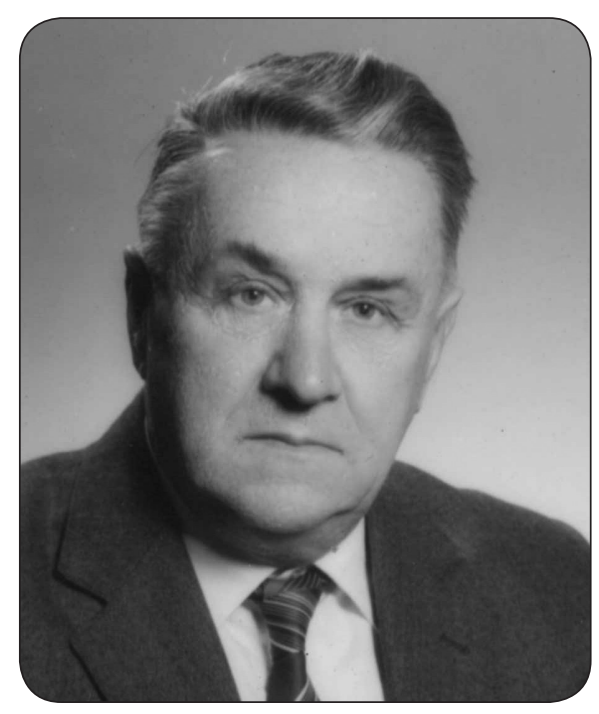

\section{Igor Maver}

In its $93^{\text {rd }}$ year, the life and fruitful academic endeavours of Professor Janez Stanonik, long-time head of the Department of Germanic Languages and Literatures, Dean of the University of Ljubljana's Faculty of Arts, and a full member of the Slovenian Academy of Sciences and Arts, came to an end. From the period immediately after World War II - he enrolled in Germanic Studies in 1945 - he researched English and American literature of the $19^{\text {th }}$ and $20^{\text {th }}$ centuries. He devoted much attention to how literature intersects with other arts and folk traditions. He studied the literature of Slovenian emigrants in the United States, as well as the history of cultural ties between Slovenia and both the United Kingdom and the United States. In his linguistic studies he examined the etymological parallels between Slovenian and English, while in the field of German Studies he dealt with early German literature in its interaction with Slovenia and literary Slovenian literature in the Habsburg and Austro-Hungarian Monarchy. In 1981, Professor Stanonik organized and directed a large and high-profile international symposium in Ljubljana on Louis Adamič, the American writer of Slovenian descent, later editing the comprehensive proceedings. This breakthrough event marked the advent of in-depth academic research into the Slovenian diaspora and emigrant press in the United States, and Slovenian emigrant literature began to be seen as being equal to Slovenian literature in the homeland. Given the strong political prejudices of the time, this was not easy and by no means self-understood. 
With his many research contributions on Slovenian emigrants in the United States, Professor Stanonik later cooperated with us, his Slovenian American Studies colleagues, in publishing, for example, in Enciklopedija Slovenije, but also in many other forums. At this point one should note the many volumes of Slovenska izseljenska knjiženost - the first exhaustive research of Slovenian emigrant literature around the world - for which he wrote studies from the areas of the older American period and the early Slovenian immigration to the United States.

In 1968 Professor Stanonik founded the scientific journal Acta Neophilologica, editing it until 2000. The journal was initially supported by American Slovenians who worked as professors in North America, including Canada, and who contributed papers to Acta - a fact of which Professor Stanonik was especially proud. Published in the journal were, among other things, a series of studies on Slovenian emigration, the emigrant press, and literature written by Slovenian and foreign literary historians, many of whom were of Slovenian origin and living abroad. These articles were the first instances of research on Slovenian emigrant literature, especially in the United States, Canada, Australia, and also in colonial Mexico.

Professor Janez Stanonik - Noni to his friends, acquaintances, but also to his students - was a long-time professor of English and American Literature and over the years a mentor to many Slovenian students of English and American Studies. Abroad, he enjoyed a fine reputation as a researcher and an erudite scholar, and everywhere he sought to make valid Slovenian scholarship and research. Noni was, as all of us who knew him are aware, a witty interlocutor who revelled in linguistic acrobatics.

I remember arriving fresh from Slovenia for my research stay at Stanford University and being immediately asked by my American colleagues whether I knew Professor Stanonik. His 1962 English-language book Moby Dick, The Myth and the Symbol was an academic tour de force on the mythology and symbolism of the white whale. In it, he pointed out new sources for Herman Melville's iconic novel, and the study was seminal also for American literary scholars, and it is still cited today. He proved that the novel is basically a parody of medieval legends about so-called grateful mythological animals and that visible in the work are a number of European, mainly folk, influences and motifs.

If it is true that development rests on the shoulders of past giants, it is certainly true of Professor Stanonik's scholarly work and activities at what was the Faculty of Arts' Department of Germanic Languages and Literatures (later divided into two independent departments). After the destruction of the German library during World War II, Professor Stanonik endeavoured and managed not only to renovate the library but also to supplement and expand the departmental library of the Faculty of Arts. He made significant contributions to the renewal of the study programmes in English and American studies, moving them in the direction of 
teaching modern English language and various literatures in English. As one of the most important founders of what was then the Department of English and German Studies at the Faculty of Arts, he was in many ways a visionary spirit. Immensely open to foreign knowledge, he remained keenly aware of the importance that developing Slovenian literary studies, English, American and German Studies, as well as the humanities as a whole, had for Slovenian autonomy and Slovenian identity.

Noni wrote and researched until the end, which kept him mentally agile for many years; indeed, he published his final article at the age of 91. Let me conclude this brief overview of Professor Stanonik's scientific opus by making reference to the Anglo-Saxon heroic epic Beowulf. This work, which in many ways is the seminal work of English literature from the early Middle Ages, was particularly close to Noni's heart. His former students remember how he, while interpreting, truly lived with the old Germanic heroes, less with Beowulf than with the demi-human violent monster Grendel and Grendel's mother, who wanted to avenge her son's death. The story's alliterative lines sometimes moved Noni so much that he, an inveterate smoker, would suddenly put a cigarette between his lips so that he could continue his lecture. His unlit cigarette would, to the delight of his student listeners, dance back and forth. Not until after the lecture would Noni light up, in the hall.

Behold, we know not anything;

I can but trust that good shall fall

At last - far off - at last, to all,

And every winter change to spring.

So runs my dream: but what am I?

An infant crying in the night:

An infant crying for the light:

And with no language but a cry.

Alfred, Lord Tennyson

Igor Maver

University of Ljubljana, Slovenia igor.maver@guest.arnes.si 